\title{
Seabird diet changes in northern Hudson Bay, 1981-2013, reflect the availability of schooling prey
}

\author{
Anthony J. Gaston ${ }^{1, *}$, Kyle H. Elliott ${ }^{2}$ \\ ${ }^{1}$ Environment Canada - National Wildlife Research Centre, Ottawa, ON K1A 0H3, Canada \\ ${ }^{2}$ Department of Biological Sciences, University of Manitoba, Winnipeg, MB R3T 2N2, Canada
}

\begin{abstract}
Ongoing climate change is altering Arctic marine ecosystems with major consequences for food-webs. Seabirds, by foraging over large marine areas but returning regularly to their breeding colonies, provide a good medium for tracking such changes. We studied the prey delivered to nestling thick-billed murres Uria lomvia at a colony in northern Hudson Bay, Canada, over the period 1981-2013. During that period, ice conditions in the region altered substantially, with earlier break-up and clearance. This change was not gradual but mainly occurred in the mid1990s. Breeding chronology also advanced, but not as fast as early summer ice clearance advanced. Ice conditions strongly affected diet, presumably reflecting the change in the timing of breeding relative to ice clearance. Of the dominant species in the diet, the proportion of Arctic cod Boreogadus saida decreased and the proportion of capelin Mallotus villosus increased over the $33 \mathrm{yr}$ period, even after ice effects were taken into account, suggesting a progressive and cumulative effect of environmental change on the marine community. Those cumulative changes were manifested primarily in the diet representation of the most frequent taxa (cod and capelin), with variation in secondary diet components being driven by the availability of the dominant taxa. Diet diversity, representing an increase in the proportion of benthic fish (stichaeids, zoarcids, pholids and sculpins) and invertebrates (squid, amphipods and crustaceans), increased when ice cover was low, and hatching was late relative to ice break-up. Chick growth rates were low when the proportion of benthic fish was high. Hence, although it appears that growth rates are influenced by diet composition, it is more likely that they reflect the availability of the dominant schooling prey species, rather than any nutritional deficiency in benthic species.
\end{abstract}

KEY WORDS: Ice cover · Climate change $\cdot$ Forage fish $\cdot$ Thick-billed murre $\cdot$ Uria lomvia

\section{INTRODUCTION}

Under the influence of climate change, Arctic seaice has been retreating over recent decades, with break-up becoming earlier while freeze-up becomes later (Gagnon \& Gough 2005, Hochheim \& Barber 2010, Hochheim et al. 2010, Stammerjohn et al. 2012). Arctic seabirds depend on the presence of open water to feed, and consequently spring ice break-up and clearance of sea-ice sets the timetable for subsequent breeding activities (Gaston et al. 2009, Smith \& Gaston 2012). Spring ice break-up may also be influential in determining the timing of other events within the food web (e.g. phytoplankton blooms: AMAP 2011; ringed seal dispersal: Chambellant 2010), hence affecting seabird foraging success and potentially population dynamics (Gaston et al. 2009, Smith \& Gaston 2012). The timing of both break-up and freeze-up likely affect the ecology of Arctic seabirds, but, of the 2, the timing of ice breakup is the most likely to affect reproduction (Gaston et al. 2012). This is especially true for those species tied to returning to large colonies which have sometimes existed in the same location for centuries (e.g. Gaston 
\& Donaldson 1996) and for which emigration between colony sites is likely to take generations, rather than happening from year to year (Gaston 2004). Birds adopting this conservative strategy with respect to nesting location cannot easily adjust to changing conditions by shifting their breeding site, necessitating other adjustments to changing environmental conditions.

To understand the likely consequences for Arctic seabirds and for their prey organisms of the climate changes currently underway, we need to better understand the role played by ice break-up and other climate variables in determining inter-year variations in prey availability. In this paper we examine a $33 \mathrm{yr}$ dataset relating to the breeding biology and nestling diet of thick-billed murres Uria lomvia in northern Hudson Bay, Canada, to explore the role of environmental conditions in determining the timing of breeding and changes in diet that have already been identified (Gaston et al. 2003, 2012) and the effects of such changes in diet on nestling growth.

Seabird diets can be useful for interpreting changes in prey populations (e.g. Barrett 2002, Deguchi et al. 2004, Hedd et al. 2006, Piatt et al. 2007, Springer et al. 2007, Renner et al. 2012). Most studies are based on nestling diets as these can be observed or sampled non-destructively (Barrett et al. 2007). The food delivered to nestlings in many cases diverges from the adult diet, especially in species where food is transported externally, held in the bill, in which case larger prey items, providing greater efficiency in transport, make up a higher proportion of food items in nestling diets (Thaxter et al. 2013). Although nestling and adult diets may not be identical they normally encompass a similar range of prey organisms, and individual specializations tend to be reflected in both adult and offspring diets (Woo et al. 2008, Provencher et al. 2013). A key result from numerous seabird dietary studies is that seabird productivity is associated with one or a few key species, and that when those key species become less available the diet becomes more diversified (Hedd et al. 2006, Schrimpf et al. 2012, Hatch 2013).

The physical and biological oceanography of Hudson Bay is poorly characterized and monitored relative to many other parts of the Arctic (Hochheim et al. 2010, Stewart \& Barber 2010). Therefore, information from seabirds may be particularly valuable in detecting changes in Hudson Bay marine ecosystems. Furthermore, the direct entry of air masses from the Pacific and Atlantic Oceans into the Hudson Bay is buffered by mountains and distance, and there are few topographical features within the region to modify local climates (Maxwell 1986, Stewart \& Barber 2010), leading to a homogenous Arctic ecosystem relatively unaffected by external influences. Ice freeze-up and break-up dates in the Hudson Bay are primarily associated with local surface air temperature and ocean circulatory processes (Hochheim et al. 2010, Stewart \& Barber 2010), although global processes - particularly, energy waves associated with Pacific and Atlantic oscillations - do impact freeze-up dates in the Hudson Bay via their influence on air temperature (Hochheim \& Barber 2010, Hochheim et al. 2011, Gaston et al. 2012). Likewise, because the Hudson Bay is only connected to the Arctic and Atlantic Oceans via small straits at its northern edge, marine communities are impoverished relative to other marine environments at similar latitudes, and changes in marine communities through the immigration of more boreal elements are likely to be slow in occurring.

Previous publications relating to older subsets of the same data have dealt with nestling diet changes that occurred during a period of step change in northern Hudson Bay ice conditions (Gaston et al. 2003, 2012) and with changes in the overall diet expressed as principal components within a multivariate framework (Smith \& Gaston 2012). In this paper we addressed (1) how individual prey taxa and overall prey diversity are affected by ice conditions, the timing of ice conditions relative to breeding, sea-surface temperature (SST) and air temperature; and (2) how nestling growth is impacted by diet variation and by changes in timing of breeding. In addition, we examined whether the general principle that diet diversifies when preferred prey is scarce (Esterbrook \& Dunham 1976, Pyke et al. 1977, Pyke 1984) applies to these marine predators. In doing so, we attempted to infer causality within a hierarchy of interrelated variables, based on the assumption that physical changes precede biological changes and that birds acquire prey by adopting particular feeding strategies that may not be optimal in a given year.

\section{MATERIALS AND METHODS}

Observations were made at the thick-billed murre Uria lomvia colony near Cape Pembroke, Coats Island $\left(62.947^{\circ} \mathrm{N}, 82.015^{\circ} \mathrm{W}\right)$, during $1981,1984-$ 2011 and 2013. 


\section{Diet}

Diet data were derived from watches carried out to observe prey delivered to nestlings. During 1981 and 1984-1987, fish were observed opportunistically, as and when work and conditions allowed. From 1988 onwards most observations were made during 3 or more all-day watches carried out at evenly spaced intervals over the chick-rearing period (feeding watches), although additional opportunistic records were also included. Up to 1992 many sightings were made through binoculars at ranges of up to $40 \mathrm{~m}$, and at such distances some taxa could not be accurately distinguished. From 1993 onwards all feeding watches were carried out from a blind where the majority of deliveries observed took place within $5 \mathrm{~m}$ of the observer, allowing accurate identification of $>80 \%$ of prey brought in. Observers had binoculars, but deliveries took place very rapidly, and the majority of prey items recorded from 1993 onwards were identified with the naked eye. Because of the distance at which observations were made, up to 1992 many deliveries were classified as simply 'sculpins' (Cottidae; 4 genera known from the colony; Elliott \& Gaston 2008) or 'blennies' (Stichaeidae, Pholidae, Zoarcidae; 7 genera; Elliott \& Gaston 2008). The occurrence of prey taxa was scored for each year as the proportion (percent by number) of all prey deliveries identified in that year (Table S1 in the Supplement at www.int-res.com/articles/suppl/m513 p211_supp.xls). More than 95\% of deliveries consisted of a single prey item. Occasionally $>1$ item was delivered, but in such cases the items were usually of the same species. In the rare cases $(<1 \%)$ where $>1$ taxon was delivered at once, the 2 taxa were both counted. For some analyses the proportions of the 3 schooling fishes (Boreogadus, Mallotus and Ammodytes) were combined.

The diversity of prey delivered was expressed using the Shannon diversity index: $H^{\prime}=-\Sigma p_{i} \times \ln \left(p_{i}\right)$, where $p_{i}$ is the proportion of all items delivered constituted by species $i$ (Shannon 1948, Hill 1973). The index was calculated for years from 1993 onwards, when different genera of stichaeids, zoarcids and pholids were identified. For inclusion in principal component analyses (PCA; see 'Statistical analyses'), we estimated $H^{\prime}$ for the period 1988-1992 (based on the reduced diversity of fish identified in 1988-1992) by interpolating the actual value of $H^{\prime}$ from the relationship between the actual $H^{\prime}$ and reduced $H^{\prime}$ from the 1993-2013 dataset $\left(\mathrm{R}^{2}=0.97\right)$. Sculpins were lumped in all analyses, as the identification of different genera was considered less reliable than other taxa.

\section{Timing of breeding}

Each year a sample of 60 to $100($ mean $=87$ ) murre eggs was marked during incubation and visited every $2 \mathrm{~d}$ to ascertain the date of hatching. The median date of hatching for this sample of eggs was used as an index of timing of breeding ('median hatch', 1986 onwards), as well as the difference between the median date of hatching and the date of $50 \%$ ice clearance from the local area, 'Northern Hudson Bay Narrows' ('relative date of hatch'; see Gaston et al. 2012 and next subsection). Nestlings were weighed every 2 to $3 \mathrm{~d}$ and the mass on Day 14 (hatching = Day 1), either measured directly or estimated by linear interpolation, was used as a measure of nestling growth rate. The earliest age at which nestling murres begin to depart from the colony voluntarily is $15 \mathrm{~d}$, so mass at Day 14 is unbiased by departure age (Gaston \& Hipfner 2000). Inter-year comparisons were based on the mean nestling mass at Day 14, based only on nestlings hatching within $7 \mathrm{~d}$ on either side of the median date of hatching.

\section{Climate and ice conditions}

Ice conditions were derived from the Canadian Ice Service ice archive using the 'Icegraph 2.0' analysis tool (http://iceweb1.cis.ec.gc.ca/IceGraph20). Local ice break-up was estimated from the Canadian Ice Service region 'Northern Hudson Bay Narrows' (NHBN), while regional ice break-up was based on the 'Hudson Bay' region (Fig. 1). Ice cover in both regions changes from $\sim 100 \%$ in winter to $\sim 0 \%$ in late summer (August-September). Break-up commences in May (Prinsenberg 1986). Indices of annual ice conditions were derived from the extent of ice in each region on $2 \mathrm{July}$, the date closest to having an average of $50 \%$ ice cover during the period 1971-2012 for the 2 areas used. Sea-surface temperatures (SST) were obtained from the NOAA website http://nomad3.ncep.noaa.gov/png, using the area bounded by $61-65^{\circ} \mathrm{N}$ and $80-84^{\circ} \mathrm{W}$ and averaging monthly values for June and July. Local air temperatures were obtained from the Environment Canada monitoring station at Coral Harbour, the closest climate station to the field site. Mean monthly temperature for June was used in modeling median date of hatching, as the murres arrive at the colony in late May and most have laid their eggs (and hence fixed the timing of hatching, the incubation period being very constant; Gaston \& Hipfner 2000) by the end of June (de Forest \& Gaston 1996). 


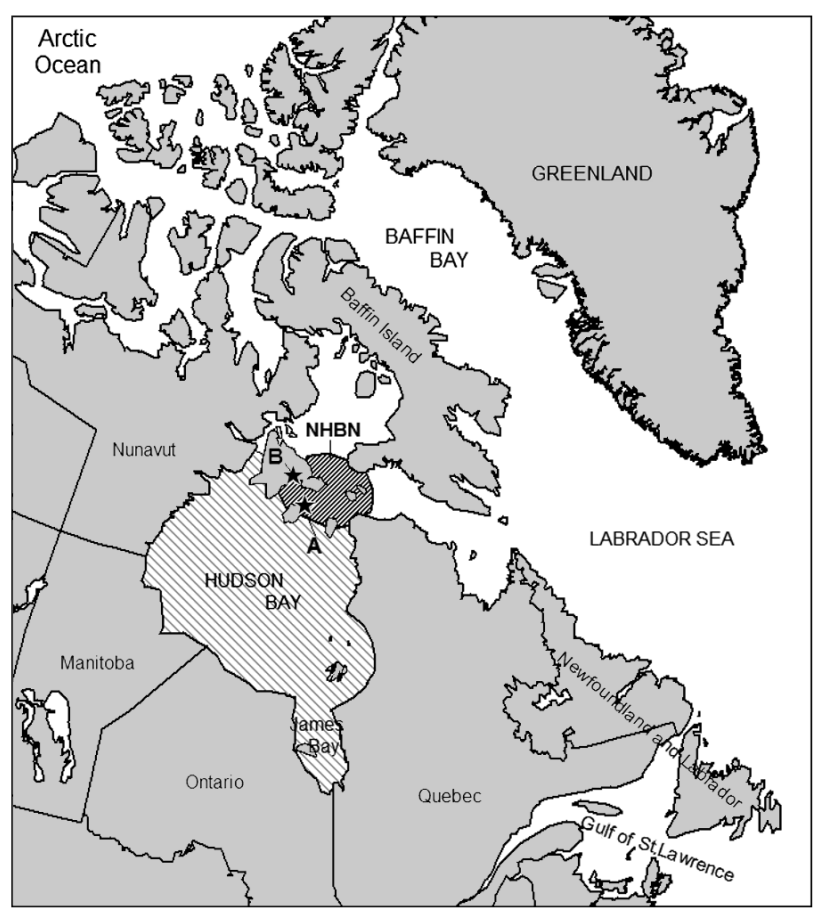

Fig. 1. Areas used in the calculation of 'local' (Northern Hudson Bay Narrows, NHBN - double-hatched) and 'regional' (Hudson Bay - single-hatched) ice cover, as defined by the Canadian Ice Service (http://iceweb1.cis.ec.gc.ca). A: Coats Island colony; B: Coral Harbour tions in Hudson Bay in the mid-1990s, when ice cover in late June dropped from an average of $\sim 70$ to $\sim 50 \%$, as noted by Gaston et al. (2012). (2) The proportions of different prey taxa in the diet were modeled using the same variables plus date of hatching in relation to date of $50 \%$ ice (relative hatch date) but omitting June air temperature as unlikely to be directly linked to foraging conditions. The first round of analyses showed that regional ice cover did not enter into any top model so, given the close correlation with local ice cover and SST, final analyses were carried out using only year, ice phase, local ice cover, SST and relative date of hatching. Only prey taxa making up $>1 \%$ of diet items, averaged over all years, were analysed (this resulted in the exclusion of 7 taxa identified in $>1$ yr). (3) Lastly, 14 d nestling mass was modeled in relation to ice phase, relative date of hatching, June air temperature (which could influence nestling energy balance) and the proportions of all prey taxa averaging $>3 \%$ of prey annually (Boreogadus, Mallotus, Ammodytes, 'all blennies', 'all sculpins' and amphipods Themisto). All these taxa were identified in all years when $14 \mathrm{~d}$ mass was measured. Full details of model comparisons are given in Table S1 in the Supplement.

We also examined the data within a multivariate framework because we anticipated that many of the

\section{Statistical analyses}

Models were constructed using the 'Best Subsets' module of Statistica 7.1's GLZ routine (Statsoft 2005), with model suitability determined from comparison of $\mathrm{AIC}_{\mathrm{c}}$ values (Akaike information constants for small samples), following the recommendations of Burnham \& Anderson (1998) and Anderson (2008). All models containing more variables than the top ranked model were discarded, as well as all multiple-variable models with $\Delta \mathrm{AIC}_{\mathrm{c}}>3 . \mathrm{AIC}_{\mathrm{c}}$ weights $\left(w_{i}\right)$ were calculated based on the remaining models. Three types of model were considered: (1) The median date of hatching was modeled for the effect of year, SST, mean June air temperature and both local and regional ice cover, as well as a 2-category variable 'ice phase', divided into years to 1995 and years from 1996 onwards, to represent the step change in ice condi-
Table 1. Pearson correlation coefficients and probabilities for time trends in physical and diet variables examined over the period 1986-2013 (no data for 2012). Correlations significant at $p<0.05$ are shown in bold. SST: sea-surface temperature

\begin{tabular}{|c|c|c|c|c|c|c|}
\hline \multirow[t]{2}{*}{ Variable } & \multirow{2}{*}{$\overline{\mathrm{n}(\mathrm{yr})}$} & \multicolumn{2}{|c|}{ All years } & \multicolumn{3}{|c|}{ — Years after 1995 - } \\
\hline & & $\mathrm{r}$ & $\mathrm{p}$ & $\mathrm{n}(\mathrm{yr})$ & $\mathrm{r}$ & $\mathrm{p}$ \\
\hline \multicolumn{7}{|l|}{ Physical } \\
\hline Local ice cover & 30 & -0.46 & 0.01 & 17 & -0.27 & 0.29 \\
\hline Regional ice cover & 30 & -0.44 & 0.02 & 17 & -0.11 & 0.66 \\
\hline June-July SST & 29 & 0.13 & 0.49 & 17 & -0.13 & 0.61 \\
\hline June air temperature & 30 & 0.27 & 0.17 & 17 & -0.15 & 0.58 \\
\hline \multicolumn{7}{|l|}{ Diet } \\
\hline Mallotus & 30 & 0.81 & $<0.001$ & 17 & 0.57 & 0.02 \\
\hline Boreogadus & 30 & 0.77 & $<0.001$ & 17 & -0.58 & 0.01 \\
\hline Ammodytes & 30 & 0.48 & 0.01 & 17 & 0.08 & 0.76 \\
\hline Leptoclinus & 24 & 0.12 & 0.61 & 17 & 0.24 & 0.35 \\
\hline Eumesogrammus & 24 & -0.27 & 0.24 & 17 & -0.09 & 0.74 \\
\hline Gymnelus & 24 & -0.1 & 0.66 & 17 & 0.31 & 0.22 \\
\hline Sculpins & 30 & -0.55 & $<0.01$ & 17 & -0.36 & 0.16 \\
\hline 'Blennies' & 30 & -0.08 & 0.68 & 17 & 0.23 & 0.37 \\
\hline Themisto & 30 & -0.05 & 0.79 & 17 & 0.03 & 0.9 \\
\hline Gonatus & 30 & 0.12 & 0.52 & 17 & -0.28 & 0.28 \\
\hline Schooling fish & 30 & -0.01 & 0.94 & 17 & -0.06 & 0.83 \\
\hline \multicolumn{7}{|l|}{ Timing of breeding } \\
\hline Median date of hatch & 27 & -0.46 & 0.01 & 17 & 0.09 & 0.72 \\
\hline Relative date of hatch & 27 & 0.37 & 0.06 & 17 & 0.04 & 0.87 \\
\hline
\end{tabular}


prey items and climatic variables would covary due to similar underlying processes. We calculated a PCA for arcsine-transformed diet components. We used the PCA primarily as a visualization tool, especially within the context of examining the components and dimensionality of diet diversity. We only included those axes with eigenvalues $>1.0$. To examine for correlations between dietary components and climatic variables within their respective multivariate spaces, we then conducted a redundancy analysis (RDA). For the multivariate analyses, we only used data from 1988 to 2013, as that was the period when fish were identified to detailed taxonomic groupings. We only included continuous variables within the RDA, and therefore excluded 'ice phase' as a climatic variable. We used R 2.14.2 for all multivariate analyses.

\section{RESULTS}

\section{Inter-correlations and time trends}

Areas of local (NHBN) and regional (Hudson Bay) ice cover were strongly correlated over the period 1981-2013 $\left(\mathrm{r}_{31}=0.66, \mathrm{p}<0.001\right)$, but there was much variation in local ice cover not explained by the larger regional situation. Both decreased significantly over the period of the study (Table 1, Figs. 2 \& 3) and both were correlated with June to July SST (local $\mathrm{r}_{31}=-0.63$, regional $\mathrm{r}_{31}=-0.54$, both $\mathrm{p}<0.001$ ). Taken over the entire period, Mallotus and Ammodytes increased, while Boreogadus and sculpins decreased (Table 1, Table S1 in the Supplement). After 1995 there were no significant time trends in the environmental variables (ice, SST; Table 1, Fig. 2), timing of breeding (median hatch, relative hatch) or any diet component other than Mallotus and Boreogadus.

\section{Timing of breeding}

Median date of hatching of thick-billed murre Uria lomvia nestlings was correlated with June to July SST $\left(\mathrm{r}_{25}=-0.74, \mathrm{p}<0.001\right)$ and ice cover on 2 July (regional and local, both $\mathrm{r}_{25}=0.66, \mathrm{p}<0.001$ ). The top best subsets model for median hatching included ice phase, regional ice cover and SST $\left(w_{i}=0.48\right.$, adjusted $\mathrm{R}^{2}=0.69$, $\mathrm{p}=0.001$; Table 1). A model including only ice phase and SST was the only other model within $\Delta \mathrm{AIC}_{\mathrm{c}}<2$ $\left(w_{i}=0.36\right)$, and SST was included in models comprising a combined $\mathrm{AIC}_{\mathrm{c}}$ weight of $>0.99$. The top-ranked model had an $\mathrm{AIC}_{\mathrm{c}}$ weight 40 times greater than the
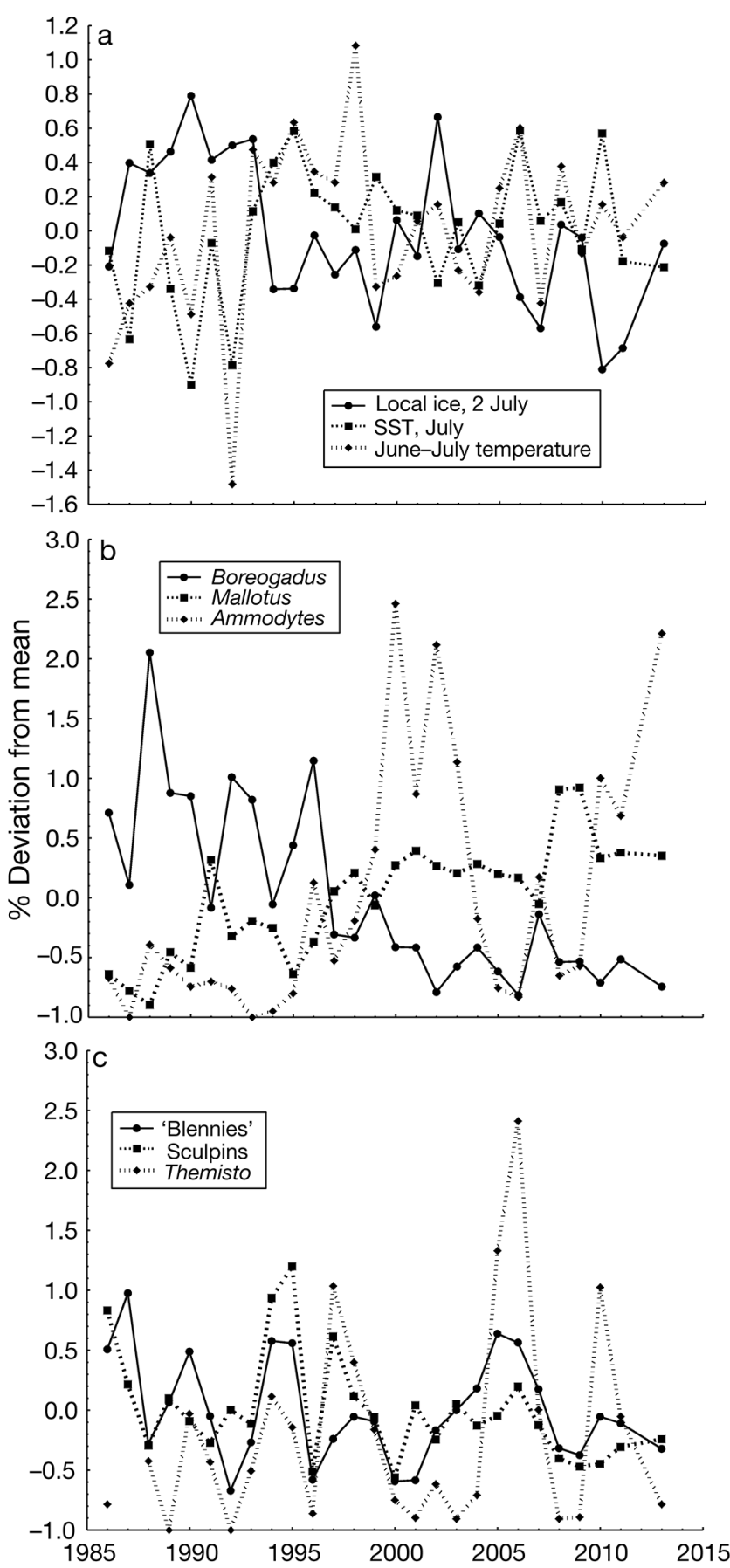

Fig. 2. Trends in primary physical variables and principle prey species, expressed as percent deviations from the mean of annual indices: (a) local ice cover on 2 July, July sea-surface temperature (SST) and mean June-July air temperatures at Coral Harbour; (b) schooling fish; and (c) benthic fish and Themisto

highest single-variable model (SST). There was no trend in date of hatching after 1995 (Fig. 3).

Despite the correlation between median date of hatching and ice cover on 2 July, estimated change in 


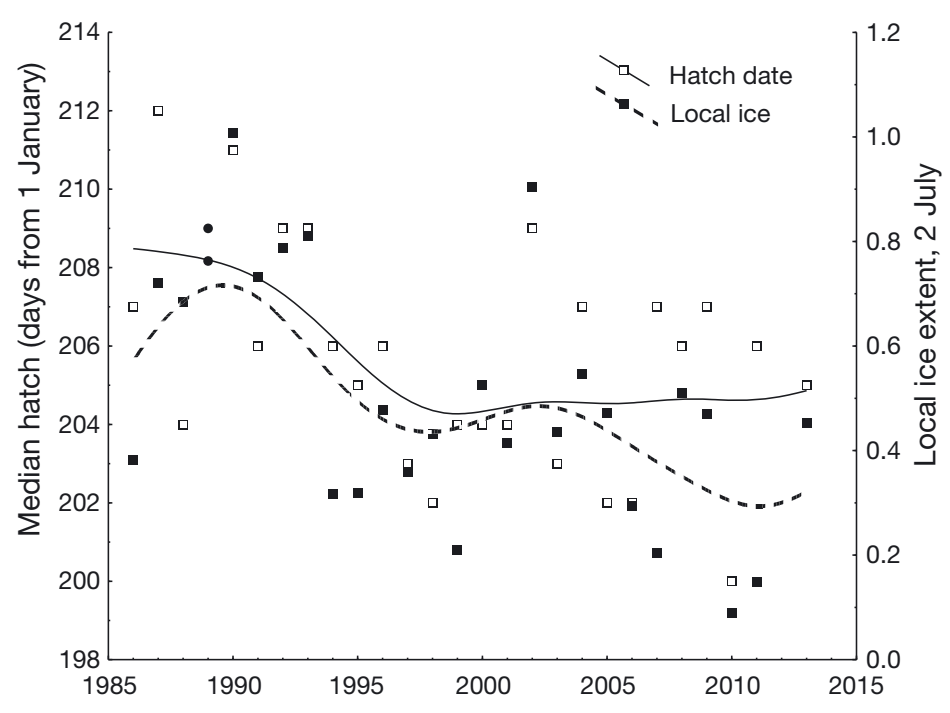

Fig. 3. Trends in median date of hatch for thick-billed murres Uria lomvia at Coats Island, Nunavut, 1984-2013 and local ice cover on 2 July. Lines are fitted by distanceweighted least-squares procedure

the former over the study period ( $\sim 5$ d, range: $19-$ 31 July) was much less than for the change in the date of $50 \%$ ice cover ( 11 d, range: 9 June-15 July). Relative date of hatching was negatively correlated with local and regional ice cover $\left(\mathrm{r}_{25}=-0.55\right.$ and -0.76 , respectively, both $\mathrm{p}<0.01$ ), but was only marginally affected by year $\left(\mathrm{r}_{25}=-0.37, \mathrm{p}=0.06\right)$.

\section{Diet}

In years after 1992 (when different benthic genera were identified separately), proportions of Leptoclinus, Gymnelus, Eumesogrammus and 'all sculpins' were all positively correlated with one another (all $\mathrm{r}_{18}$ $>0.52$, all p < 0.02; Fig. 4) and Leptoclinus, Eumesogrammus and 'all blennies' were positively correlated with Themisto (all $\mathrm{r}_{18}>0.54$, all $\mathrm{p}<0.02$; Fig. 4). Among the prey taxa for which best subsets models were run, 3 yielded no worthwhile model fit $\left(\mathrm{R}^{2}<0.1\right.$, model p > 0.1; Table 2): the stichaeid (prickleback) Leptoclinus, the squid Gonatus and the amphipod Themisto. Among the other 6 taxa modeled, none of the top models, or those within $\Delta \mathrm{AIC}_{\mathrm{C}}<2$, included regional ice cover, whereas 5 included local ice cover and 5 included the step variable 'ice phase' (Table 2). Despite the inclusion of the ice phase variable, year entered into the top models for Boreogadus and Mallotus, the 2 most common taxa in the diet, and relative date of hatching was included in the top models for Mallotus and 'all blennies'. June SST was included in the top model for Boreogadus, and was the only variable included for Eumesogrammus (Table 2).

Among the 6 taxa with models yielding $\mathrm{R}^{2}>0.1$, Mallotus increased over time, while Boreogadus decreased. Boreogadus, Mallotus and Ammodytes increased with local ice cover, while 'all blennies'

Table 2. Variables included in top models (dark colours) predicting diet components for thick-billed murres Uria lomvia at Coats Island, Nunavut, 1981-2013 ('All years') and other models within $\Delta \mathrm{AIC}_{\mathrm{c}}<2$ (light colours) — brown: positive; blue: negative. $\mathrm{AIC}_{\mathrm{c}}$ weights, adjusted $\mathrm{R}^{2}$ values, $F$ statistics and full model probabilities for the top model are also given. Grey cells were not included in the respective models. SST: sea-surface temperature; $H^{\prime}$ : Shannon's diversity index

\begin{tabular}{|c|c|c|c|c|c|c|c|c|c|c|c|c|c|c|c|c|}
\hline \multirow[t]{2}{*}{ Diet element } & \multirow{2}{*}{$\begin{array}{c}\text { Mean } \\
\% \text { of } \\
\text { prey }\end{array}$} & \multirow[t]{2}{*}{ Years } & \multicolumn{10}{|c|}{ Variables in top model } & \multirow[t]{2}{*}{$w_{i}$} & \multirow{2}{*}{$\underset{\mathrm{R}^{2}}{\mathrm{Adj}}$} & \multirow{2}{*}{$\begin{array}{c}F \\
\text { (df) }\end{array}$} & \multirow{2}{*}{$\underset{\text { (full }}{\mathrm{p}}$} \\
\hline & & & Year & $\begin{array}{c}\text { Ice } \\
\text { phase }\end{array}$ & $\begin{array}{l}\text { Reg. } \\
\text { ice } \\
\text { ext. }\end{array}$ & $\begin{array}{c}\text { Local } \\
\text { ice ext. }\end{array}$ & SST & $\begin{array}{c}\text { Rel. } \\
\text { hatch } \\
\text { date }\end{array}$ & $\begin{array}{c}\text { All } \\
\text { blenny }\end{array}$ & Themisto & Squid & $\begin{array}{l}\text { Sum } \\
\text { school. } \\
\text { fish }\end{array}$ & & & & \\
\hline Mallotus & 37.2 & All & $\mathrm{X}+$ & $\overline{X-}$ & & $x+$ & & $\overline{X-}$ & & & & & 0.27 & 0.69 & $20.1(3,23)$ & $<0.001$ \\
\hline Boreogadus & 27.7 & All & $X_{-}$ & & & $\mathrm{X}_{+}$ & $\mathrm{X}+$ & & & & & & 0.60 & 0.55 & $11.7(3,23)$ & $<0.001$ \\
\hline All 'blennies' & 11.5 & All & & $\mathrm{X}+$ & & $\mathrm{x}-$ & & $\mathrm{X}+$ & & & & & 0.48 & 0.21 & $4.4(2,24)$ & 0.02 \\
\hline All sculpins & 11.4 & All & & $\mathrm{X}+$ & & $X_{-}$ & & & & & & & 0.76 & 0.37 & $8.8(2,24)$ & 0.001 \\
\hline Ammodytes & 6.6 & All & & $X-$ & & $\mathrm{X}+$ & $x-$ & & & & & & 0.29 & 0.30 & $6.5(2,24)$ & 0.005 \\
\hline Leptoclinus & 4.1 & $>1992$ & & & & & & & & & & & & $<0.1$ & & $>0.1$ \\
\hline Gymnelus & 2.4 & $>1992$ & & $\mathrm{X}+$ & & & & & & & & & 0.73 & 0.22 & $6.4(1,18)$ & 0.02 \\
\hline Eumesogrammus & 1.3 & $>1992$ & & & & & $\mathrm{X}+$ & & & & & & 0.76 & 0.23 & $6.7(1,18)$ & 0.02 \\
\hline Gonatus & 1.1 & All & & & & & & & & & & & & $<0.1$ & & $>0.1$ \\
\hline Themisto & 3.4 & All & & & & & & & & & & & & $<0.1$ & & $>0.1$ \\
\hline $\begin{array}{l}\text { Diversity } H^{\prime}, \\
\text { physical only }\end{array}$ & & $>1995$ & & & & & & $\mathrm{X}+$ & & & & & 0.57 & 0.17 & $4.3(1,15)$ & 0.05 \\
\hline Diversity $H^{\prime}$ & & $>1995$ & $\mathrm{X}-$ & & & $\mathrm{X}-$ & $\mathrm{X}+$ & & & & & $\mathrm{X}-$ & 0.97 & 0.86 & $24.7(4,12)$ & $<0.001$ \\
\hline \multicolumn{17}{|c|}{ Timing of breeding and chick growth } \\
\hline Median hatch & & All & & $\mathrm{X}+$ & $\mathrm{X}+$ & & $x-$ & & & & & & 0.48 & 0.69 & $20.7(3,23)$ & $<0.001$ \\
\hline $\begin{array}{l}\text { 14-day mass, inc. } \\
\text { pooled schooling } \\
\text { fish }\end{array}$ & & $>1992$ & & & & & & $x-$ & $x-$ & & $x-$ & & 0.26 & 0.32 & $5.2(2,16)$ & 0.02 \\
\hline 14 days mass & & $>1987$ & & & & & & & $\mathrm{X}-$ & $x-$ & & & 0.47 & 0.17 & $5.7(1,22)$ & 0.02 \\
\hline
\end{tabular}



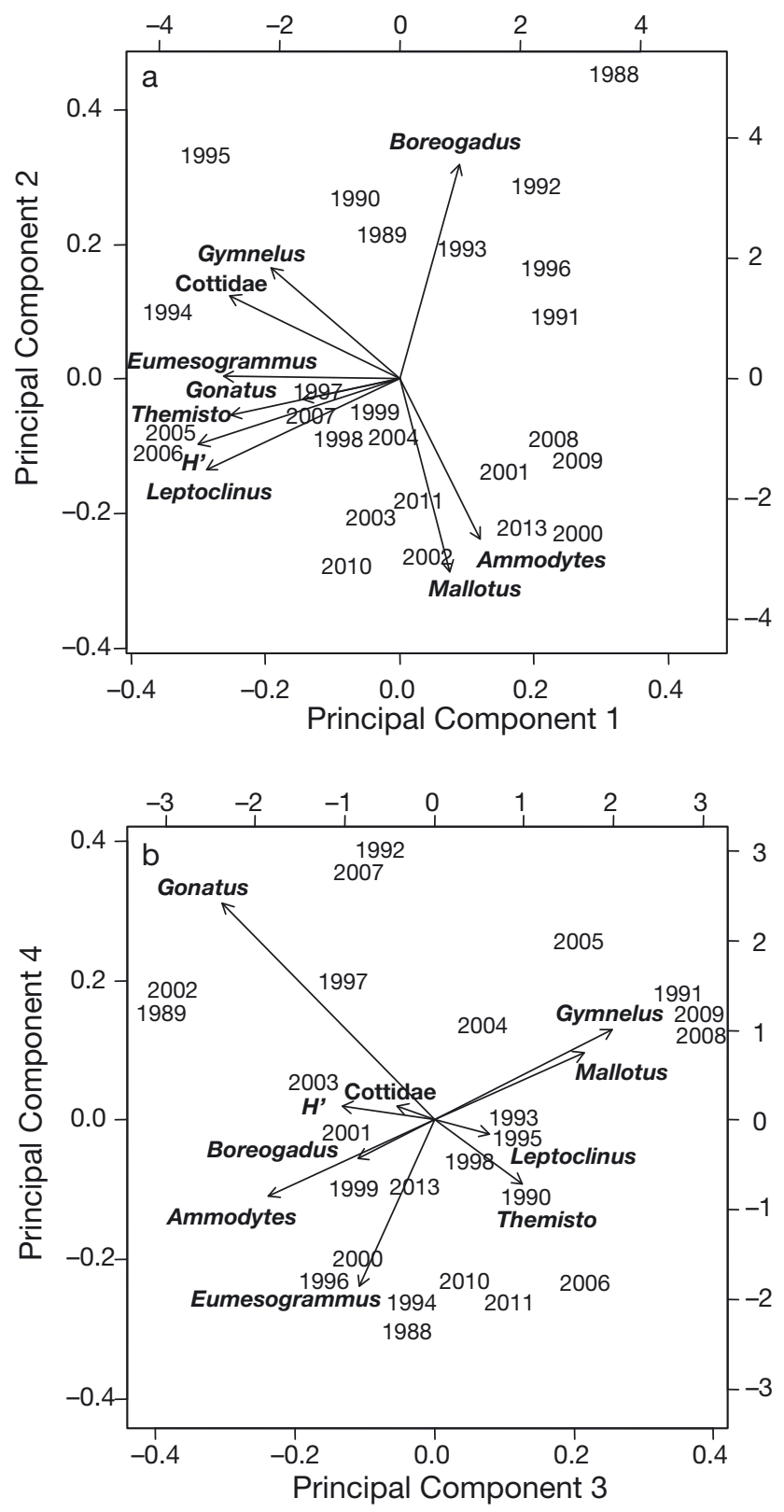

Fig. 4. Principal components analysis of thick-billed murre Uria lomvia diet variation at Coats Island, Nunavut 19882013. Principal Component 4 had an eigenvalue $<1.0$ (eigenvalue $=0.79$; percentage of variation explained $=8 \%$ ) and therefore was not included in the interpretation. SST: sea-surface temperature

and sculpins decreased (Table 2). Those taxa which increased with ice cover decreased with relative hatch date and vice versa, presumably because of the strong correlation between local ice cover and relative hatch, so Mallotus decreased in the diet as the time between hatching and $50 \%$ local ice cover increased, whereas 'all blennies' increased.
Shannon's $H^{\prime}$ was negatively correlated with all 3 species of schooling fish (significant only for Mallotus, $\mathrm{r}_{18}=0.58, \mathrm{p}=0.007$ ) and positively correlated with all other taxa $(\mathrm{p}<0.01$ for all taxa except Gymnelus, for which the relationship was not significant). When diet diversity was modeled in relation to physical variables (year, ice, SST) and relative date of hatching, only relative date of hatching appeared in the top model $\left(w_{i}=0.57\right)$, and the model including both relative date of hatching and year was within $\Delta \mathrm{AIC}_{\mathrm{c}}<2\left(w_{i}=0.20\right)$. However, if the proportion of schooling fish was included, the top model included year, local ice cover, SST and sum of schooling fish, with $w_{i}=0.97$, and no other models were within $\Delta \mathrm{AIC}_{\mathrm{c}}<2$.

Chick mass at $14 \mathrm{~d}$ was correlated with the proportion of Leptoclinus, Gymnelus and 'all blennies' in the diet (all $\mathrm{r}=0.45, \mathrm{p}=0.03$ ), but not with year or either ice cover variable. The top best subsets model contained only 'all blennies' (Table 2). When the proportions of the 3 schooling genera were pooled, the resulting top model included both relative hatching date and 'all blennies', with a higher $\mathrm{R}^{2}$ ( 0.31 vs. 0.17 ) and the model including 'all blennies' and Gonatus was also well supported $\left(\Delta \mathrm{AIC}_{\mathrm{c}}<2\right)$. None of the nonprey variables (year, June air temperature, relative date of hatching) gave $w_{i}>0.05$.

Within the multivariate analyses (Fig. 4), diet could be decomposed into 3 principal axes, each explaining $>10 \%$ of the variation in diet (Table 3). Variation in the proportion of secondary prey items (benthic prey and invertebrates) was associated with PC1 (Table 2, Fig. 4). Variation in the composition of primary, schooling prey was associated with PC2 (Boreogadus relative to Mallotus-Ammodytes) and PC3 (Mallotus relative to Ammodytes; Table 3, Fig. 4). The Shannon diversity index was heavily loaded on PC1, demonstrating that it was primarily linked to variation in the proportion of secondary prey items (benthic and invertebrate prey; Table 3, Fig. 4).

Climate variables significantly explained variation in diet (permutation test: $F_{5,19}=4.05, \mathrm{p}=0.005,199$ permutations). Climate variables that explained diet components could be decomposed into 2 main axes. The main correlate of diet was year, which explained primarily the variation in Boreogadus and Mallotus (Fig. 5). The second axis was directly associated with climate variables, especially local ice cover, which in turn was correlated with SST and hatch date. That axis primarily reflected variation in diversity. Diversity was high when ice cover was low. 
Table 3. Loadings from a principal components (PC) analysis of diet composition for thick-billed murres Uria lomvia at Coats Island, Nunavut, 1988-2013. Only axes with eigenvalues $>1.0$ are shown; no other axis explained $>10 \%$ of the variation in diet. Loadings with absolute values $<0.1$ are not shown

\begin{tabular}{|llrrr|}
\hline Species & Common name & PC1 & PC2 & PC3 \\
\hline Variation explained (\%) & & 37 & 26 & \multicolumn{1}{c|}{13} \\
Boreogadus saida & Arctic cod & 0.138 & 0.568 & -0.188 \\
Mallotus villosus & Capelin & 0.106 & -0.512 & 0.373 \\
Ammodytes hexapterus & Sandlance & 0.174 & -0.426 & -0.417 \\
Leptoclinus maculatus & Daubed shanny & -0.426 & 0.234 & 0.139 \\
Gymnelus viridis & Fish doctor & -0.283 & 0.296 & 0.443 \\
Eumesogrammus praecisus & Fourline snakeblenny & -0.388 & & -0.191 \\
Cottidae & Sculpin & -0.373 & 0.225 & \\
Themisto libellula & Amphipod & -0.372 & & 0.223 \\
Gonatus fabricii & Squid & -0.215 & & -0.539 \\
Shannon diversity index $\left(H^{\prime}\right)$ & & -0.451 & -0.170 & -0.222 \\
\hline
\end{tabular}

\section{DISCUSSION}

Timing of breeding by the murres Uria lomvia at Coats Island was associated with ice phase, regional ice conditions and SST, with SST apparently the strongest driver. Although regional ice cover was more important than local ice cover in models predicting timing of breeding by the murres, the proportions of different prey taxa in the diet was more influenced by local ice cover, being included in all top models, except those for the zoarchid (eelpout) Gymnelus and the stichaeid (prickleback) Eumesogrammus. That result was also backed up by the strong support for ice cover in relation to diet diversity within the redundancy analysis. Ice phase also appeared in top models for 5 taxa, and given the small number of 'pre-step' years included in the sample of years analysed for individual benthic genera, its exclusion from top models for Leptoclinus and Eumesogrammus is not surprising. The prominence of this variable among factors affecting murre diets confirms the importance of the step-change in marine ecosystems that occurred in Hudson Bay in the mid-1990s (Gaston et al. 2012), a change that also created a strong signal in freshwater ecosystems in the Hudson Bay lowlands (Rühland et al. 2013). Similarly, in the Antarctic, ice conditions were more important than year effects for the diet of Adélie penguins (Pygoscelis adeliae) monitored over $7 \mathrm{yr}$, with more fish consumed during years of lower ice cover (Ainley et al. 2003). Timing of hatching relative to the date of $50 \%$ ice cover appeared in 1 the top-ranked models for Mallotus (capelin) and 'all blennies', but date of hatching itself was not included in any, supporting the idea of Gaston et al. (2012) that timing of breeding per se is less important than timing relative to ice break-up, for the biology of the murres.

To date, there is little evidence that birds are adjusting their timing of breeding to match changes in ice conditions. An initial advance in timing of breeding in the period up to 1996 (Gaston \& Hipfner

Fig. 5. Redundancy analysis of thick-billed murre Uria lomvia diet at Coats Island, Nunavut, 1988-2004 relative to (a) 5 climate-related variables and (b) those same variables and chick growth rate 
1998) was followed by relative stasis. This situation contrasts with observations at Prince Leopold Island, in the high Arctic, where there was a strong correlation between date of $50 \%$ ice cover and date of laying by thick-billed murres (Hipfner et al. 2005). The lack of correlation between ice conditions and timing of breeding means that the difference between date of $50 \%$ ice and date of hatching (relative hatch date) has increased, although the significance is marginal $(\mathrm{p}=0.06)$.

The current analysis did not confirm the previous suggestion that a decrease in Boreogadus in the diet caused decreased nestling growth (Gaston \& Hipfner 1998). It appears that during the period of rapidly diminishing ice cover in the 1990s, murres may have had difficulty adapting their foraging behaviour to the changing spectrum of prey, causing a reduction in the amount of food delivered to nestlings, either through a reduced rate of delivery or through the delivery of smaller or less nutritious meals. Subsequently, either they have become more successful at foraging on capelin Mallotus, or capelin has become more abundant locally, because post-1995 there was no relationship between nestling mass and the proportion of Boreogadus delivered. Chick $14 \mathrm{~d}$ mass in several years after 2000 was high relative to that in the early 1990s.

Year entered into the top models for the 2 main prey taxa, Mallotus and Boreogadus, suggesting that trends in these populations over time were, to some extent, independent of year-to-year fluctuations in ice conditions. Likewise, in the multivariate approach, the main environmental variable influencing diet composition was year, and that was caused primarily by changes in the proportions of Mallotus and Boreogadus. This is not surprising, because individuals of both genera delivered by murres to nestlings were $>1$ yr old and therefore availability probably would have been partially related to conditions in previous years. Smith \& Gaston (2012) found that detrended diet, as represented by PC1 and PC2 in a principle components analysis, was affected primarily by local SST, with the PCs heavily weighted by the main prey species, Mallotus and Boreogadus. In the current study, year was not included in any top models for benthic fish (sculpins, 'all blennies', Leptoclinus, Gymnelus, Eumesogrammus), suggesting that there has been no secular trend in the availability of these fish. The importance of 'all blennies' in models (and overall diversity within the multivariate analyses) relating to chick mass at $14 \mathrm{~d}$ suggests that these fishes, of diverse phylogeny but all benthic and often associated with the kelp Laminaria spp. (Cairns
1987, Scott \& Scott 1988), tend to be taken more often in years when schooling prey (Boreogadus, Mallotus, Ammodytes) is less available than usual. This hypothesis is supported by the positive correlations among all the non-schooling prey taxa (benthic fish, as well as the epipelagic amphipod Themisto). Assuming these resources are relatively stable from year to year, it appears that when schooling fish are not adequately available, the Coats Island murre population diversifies its diet to include a variety of prey types, but especially those associated with bottom habitat. A similar pattern was observed in common murre Uria aalge diets in California (Ainley \& Boekelheide 1990, Ainley et al. 1996). These observations support theoretical predictions that diet will diversify as preferred species become harder to find (Estabrook \& Dunham 1976, Pyke et al. 1977, Pyke 1984). The fact that diversity has declined over time apparently reflects the fact that Mallotus has continued to increase in the diet.

The most important parameter associated with variation in diet, as measured by loadings on the first principal component (Table 3), was the proportion of secondary prey items (benthic fish and invertebrates). A similar analysis examining average energy content delivered to offspring per year (Table 3 in Smith \& Gaston 2012) also showed a strong loading of invertebrates and benthic prey on PC1, suggesting that high levels of secondary prey items are associated with low-energy delivery rates. The secondand third-most important parameters associated with variation in diet, as measured by loadings on the second and third principal components (Table 3), were the proportion of the schooling prey items Boreogadus, Mallotus and Ammodytes. Years that were low in Boreogadus tended to be high in both Mallotus and Ammodytes (PC2), but, within lowBoreogadus years (PC3), years with a high proportion of Ammodytes were characterized as also having a high proportion of deep-water secondary species (Gonatus and Eumesogrammus), and years with a high proportion of Mallotus also had a high proportion of shallow-water secondary species (Gymnelus). In high-Mallotus years gravid Mallotus were observed being fed to nestlings (Elliott et al. 2009a). Perhaps foraging behaviour during high-Mallotus years involved the capture of spawning fish and associated foraging in shallow, near-shore environments, with the consequence that other shallow-water prey were captured disproportionately. In contrast, foraging behaviour during high-Ammodytes years may have involved foraging in deeper water for openwater schools. 
Several benthic fish species are preyed on by specialist individuals which use particular feeding strategies (Woo et al. 2008, Elliott et al. 2008, 2009b). These birds maintain their specialization across years (Woo et al. 2008), and there is no evidence that, in terms of total calories received, nestling nourishment differs among the various prey specialties, or between specialists and generalists. Consequently, the lowering of chick growth rates in years when a higher proportion of benthic fish is being delivered could be the result of non-specialists turning to benthic prey when schooling prey is comparatively scarce in the chick-rearing period and being less successful at finding such prey. Such conditions appear to be most likely when hatching is delayed relative to the timing of $50 \%$ ice cover and when local ice cover is low. All the schooling prey showed a positive relationship with local ice cover, whereas benthic fish had a negative relationship (Table 1).

We document a change in marine communities within Hudson Bay associated with changing local conditions. Although a few long-distance migrants, such as orcas Orcinus orca and razorbills Alca torda may be able to directly and quickly respond to changing conditions by moving into the bay to breed (Gaston \& Woo 2008, Higdon \& Ferguson 2009), many of the changes within the relatively isolated marine community must occur through variation in the abundance of pre-existing community members (e.g. an American eel Anguilla rostrata in the St Lawrence estuary cannot immediately take advantage of ideal oceanographic conditions in James Bay). As such, murre diets at Coats Island do not demonstrate the arrival of new prey, but rather a change in the proportion of community members already present, in particular, a shift from Boreogadus to Mallotus and Ammodytes. Mallotus dominates beluga Delphinapterus leucas diet in southern Hudson Bay (Kelley et al. 2010), and Ammodytes has dominated ringed seal Phoca hispida diet in western Hudson Bay since at least 1998 (Chambellant 2010). The changes seen at Coats Island may therefore represent a northward spread of Mallotus and Ammodytes, or of their spawning grounds, within Hudson Bay.

The switch away from Boreogadus occurred rapidly and so far irreversibly in the mid-1990s, despite substantial short-term, year-to-year variation in ice conditions (Gaston et al. 2012; Table 1, Figs. 3 \& 5). The increased use of capelin from the mid-1990s is consistent with the movement towards the Arctic and/or an increase in abundance of a subarctic fish previously at the margins of its historical distribution, under conditions of increasing ocean temperatures (Carscadden et al. 2013).

The step change in the mid-1990s impacted nestling condition at departure, as the fledging mass of murre nestlings declined steeply after the mid1990s (Gaston et al. 2012). Mass at departure is correlated with subsequent survival to recruitment (Hipfner 2001). In a similar manner, the diet of many seabirds in the northern Atlantic and Pacific have shown stepwise changes, particularly, though not exclusively, in the abundance of Ammodytes and Mallotus (Barrett et al. 1997, Anderson \& Piatt 1999, Barrett 2002, Montevecchi 2007, Hatch 2013). Those changes often reflected apparent warm-to-cold or cold-to-warm regime shifts in physical oceanography (Anderson \& Piatt 1999, Montevecchi 2007, Hatch 2013). The response of the biological community is often rapid and difficult to reverse, once environmental change reaches a tipping point (Overland et al. 2010, Spencer et al. 2012). In our case, the cold-towarm shift was clearly associated with a reduction in ice cover, as ice is an important habitat for Boreogadus (Crawford \& Jorgenson 1993, Gradinger \& Bluhm 2004). Our dataset differs from datasets derived from temperate systems in that (1) the coldto-warm shift can be clearly linked to a change in physical habitat (ice) and (2) some regime shifts appear to have occurred periodically for centuries, but the mid-1990s shift in Hudson Bay forms part of a general trend in Arctic sea ice cover, possibly associated with anthropogenic climate change (AMAP 2011) and therefore unlikely to be reversed. Our ability to detect the trends that we have described is greatly enhanced by the availability of a wide range of secondary prey at Coats Island, a situation that also exists at other low Arctic murre colonies in Canada (Gaston 1985).

\section{CONCLUSIONS}

Compared with changes in the timing of ice breakup in Hudson Bay, change in the timing of breeding of murres Uria lomvia has been small and timing has not advanced since the step change in about 1995. The subsequent mismatch between ice conditions and murre egg-laying has resulted in ice phase and local ice conditions being the most widespread factors affecting diet variables. Both appear in top models for 5 out of 6 taxa examined. When ice cover was low on 2 July and hatching was late relative to ice break-up, diet included a higher than average proportion of benthic fish and a lower than average pro- 
portion of schooling fish. Diet diversity was inversely related to the proportion of schooling fish. Chick mass at $14 \mathrm{~d}$ of age was inversely related to the proportion of benthic fishes in the diet, suggesting that feeding nestlings on these fish was sub-optimal for the population as a whole, although, based on previous work (Elliott et al. 2008, 2009a), individual specialists can provision their nestlings adequately on benthic fishes. Based on $14 \mathrm{~d}$ nestling mass as an indicator of diet quality, diet diversity increased when feeding conditions were sub-optimal, supporting previous observations of seabird diet breadth in relation to reproductive success and other measures of breeding conditions (e.g. Takahashi et al. 2001, Hedd et al. 2006, Waluda et al. 2012).

When diet analysis is based on the proportions of different taxa in the prey, it is inevitable that increases in one taxon will be at the expense of one or more other taxa. Consequently, it seems appropriate to base interpretations on convergences and divergences among prey taxa, rather than on individual trends. The 2 most important taxa in nestling diets (Mallotus, Boreogadus) showed secular trends, even after environmental variables were taken into account, suggesting that cumulative environmental effects were causing progressive changes in local marine communities. There was no evidence for secular trends in other diet elements. Inter-year variation in the dominant diet taxa probably relates to relative availability, but variation in secondary diet taxa is probably driven by the availability of the dominant taxa.

Acknowledgements. Research at Coats Island has been funded by Environment Canada with logistic support from the Polar Continental Shelf Project of Natural Resources Canada. K.H.E. received financial support through a NSERC Vanier Canada Graduate Scholarship, ACUNS Garfield Weston Northern Studies scholarship and AINA Jennifer Robinson Scholarship. We thank all those numerous individuals who contributed to observations of food deliveries at Coats Island, especially Mark Hipfner and Kerry Woo. Thanks to Paul Smith for statistical advice.

\section{LITERATURE CITED}

Ainley DG, Boekelheide RJ (1990) Seabirds of the Farallon Islands. Stanford University Press, Stanford, CA

Ainley DG, Spear LB, Allen SG, Ribic CA (1996) Temporal and spatial patterns in the diet of the common murre in California waters. Condor 98:691-705

> Ainley DG, Ballard G, Barton KJ, Karl BJ, Rau GH, Ribic CA, Wilson PR (2003) Spatial and temporal variation of diet within a presumed metapopulation of Adélie penguins. Condor 105:95-106
AMAP (Arctic Monitoring and Assessment Programme) (2011) Snow, water, ice and permafrost in the Arctic (SWIPA): climate change and the cryosphere. AMAP, Oslo

Anderson DR (2008) Model based inference in the life sciences: a primer on evidence. Springer, New York, NY

Anderson PJ, Piatt JF (1999) Community reorganization in the Gulf of Alaska following ocean climate regime shift. Mar Ecol Prog Ser 189:117-123

- Barrett RT (2002) Atlantic puffin Fratercula arctica and common guillemot Uria aalge chick diet and growth as indicators of fish stocks in the Barents Sea. Mar Ecol Prog Ser 230:275-287

- Barrett RT, Bakken V, Krasnov JV (1997) The diets of common and Brünnich's guillemots Uria aalge and U. lomvia in the Barents Sea region. Polar Res 16:73-84

> Barrett RT, Camphuysen CJ, Anker-Nilssen T, Chardine JW and others (2007) Diet studies of seabirds: a review and recommendations. ICES J Mar Sci 64:1675-1691

Burnham KP, Anderson DR (1998) Model selection and inference: a practical information-theoretic approach. Springer-Verlag, New York, NY

> Cairns DK (1987) Diet and foraging ecology of black guillemots in northeastern Hudson Bay. Can J Zool 65: 1257-1263

Carscadden JE, Gjøsæter H, Vilhjálmsson H (2013) A comparison of recent changes in distribution of capelin (Mallotus villosus) in the Barents Sea, around Iceland and in the Northwest Atlantic. Prog Oceanogr 114:64-83

Chambellant M (2010) Hudson Bay ringed seal: ecology in a warming climate. In: Ferguson SH, Loseto LL, Mallory ML (eds) A little less Arctic. Springer-Verlag, New York, NY, p 137-158

Crawford RE, Jorgenson JK (1993) Schooling behaviour of arctic cod, Boreogadus saida, in relation to drifting pack ice. Environ Biol Fishes 36:345-357

de Forest LN, Gaston AJ (1996) The effect of age and timing of breeding on reproductive success in the thick-billed murre. Ecology 77:1501-1511

> Deguchi T, Watanuki Y, Niizuma Y, Nakata A (2004) Interannual variations of the occurrence of epipelagic fish in the diets of the seabirds breeding on Teuri Island, northern Hokkaido, Japan. Prog Oceanogr 61:267-275

Elliott KH, Gaston AJ (2008) Mass-length relationships for fishes delivered to nestling thick-billed murres Uria lomvia at Coats Island, 1981-2006. Mar Ornithol 36: 25-34

- Elliott KH, Davoren GK, Gaston AJ (2008) Time allocation by a deep-diving bird reflects prey type and energy gain. Anim Behav 75:1301-1310

> Elliott KH, Bull R, Davoren GK, Gaston AJ (2009a) Underwater and above-water search patterns of an Arctic seabird: reduced searching at small spatiotemporal scales. Behav Ecol Sociobiol 63:1773-1785

> Elliott KH, Woo K, Gaston AJ (2009b) Specialization in murres: the story of eight specialists. Waterbirds 32 : 491-506

- Estabrook GF, Dunham AE (1976) Optimal diet as a function of absolute abundance, relative abundance, and relative value of available prey. Am Nat 110:401-413

Gagnon AS, Gough WA (2005) Trends in the dates of ice freeze-up and breakup over Hudson Bay, Canada. Arctic 58:370-382

Gaston AJ (1985) The diet of thick-billed murre chicks in the eastern Canadian arctic. Auk 102:727-734 
Gaston AJ (2004) Seabirds: a natural history. Yale University Press, New Haven, CT

Gaston AJ, Donaldson G (1996) Peat deposits and thickbilled murre colonies and Hudson Strait and northern Hudson Bay: clues to post-glacial colonization of the area by seabirds. Arctic 48:354-358

Gaston AJ, Hipfner JM (1998) The effect of ice conditions in northern Hudson Bay on breeding thick-billed murres (Uria lomvia). Can J Zool 76:480-492

Gaston AJ, Hipfner JM (2000) Thick-billed murre (Uria lomvia). In: Poole A, Gill F (eds) The birds of North America, No. 497. The Birds of North America Inc., Philadelphia, PA

Gaston AJ, Woo K (2008) Razorbills (Alca torda) follow subarctic prey into the Canadian Arctic: colonization results from climate change? Auk 125:939-942

Gaston AJ, Woo K, Hipfner JM (2003) Trends in forage fish populations in northern Hudson Bay since 1981, as determined from the diet of nestling thick-billed murres Uria lomvia. Arctic 56:227-233

Gaston AJ, Gilchrist HG, Mallory ML, Smith PA (2009) Changes in seasonal events, peak food availability and consequent breeding adjustment in a marine bird: a case of progressive mis-matching. Condor 111:111-119

Gaston AJ, Smith PA, Provencher J (2012) Discontinuous change in ice cover in Hudson Bay in the 1990s and some consequences for marine birds and their prey. ICES J Mar Sci 69:1218-1225

Gradinger RR, Bluhm BA (2004) In situ observations on the distribution and behaviour of amphipods and Arctic cod (Boreogadus saida) under the sea ice of the High Arctic Canada Basin. Polar Biol 27:595-603

> Hatch SA (2013) Kittiwake diets and chick production signal a 2008 regime shift in the Northeast Pacific. Mar Ecol Prog Ser 477:271-284

$>$ Hedd A, Bertram DF, Ryder JL, Jones IL (2006) Effects of interdecadal climate variability on marine trophic interactions: rhinoceros auklets and their fish prey. Mar Ecol Prog Ser 309:263-278

> Higdon JW, Ferguson SH (2009) Loss of Arctic sea ice causing punctuated change in sightings of killer whales (Orcinus orca) over the past century. Ecol Appl 19: 1365-1375

Hill MO (1973) Diversity and evenness: a unifying notation and its consequences. Ecology 54:427-432

> Hipfner JM (2001) Fitness-related consequences of relaying in an Arctic seabird: survival of offspring to recruitment age. Auk 118:1076-1080

Hipfner JM, Gaston AJ, Gilchrist HG (2005) Variation in egg-size and laying date in thick-billed murre populations breeding in the Low Arctic and High Arctic. Condor 107:657-664

> Hochheim KP, Barber DG (2010) Atmospheric forcing of sea ice in Hudson Bay during the fall period, 1980-2005. J Geophys Res 115:C05009, doi:10.1029/2009JC005334

Hochheim K, Barber DG, Lukovich JV (2010) Changing sea ice conditions in Hudson Bay, 1980-2005. In: Ferguson $\mathrm{SH}$, Loseto LL, Mallory ML (eds) A little less Arctic. Springer-Verlag, New York, NY, p 39-51

Hochheim KP, Lukovich JV, Barber DG (2011) Atmospheric forcing of sea ice in Hudson Bay during the spring period 1980-2005. J Mar Syst 88:476-487

Kelley TC, Loseto LL, Stewart REA, Yurkowski M, Ferguson SH (2010) Importance of eating capelin: unique dietary habits of Hudson Bay beluga. In: Ferguson SH, Loseto
LL, Mallory ML (eds) A little less Arctic. Springer-Verlag, New York, NY, p 53-69

Maxwell JB (1986) A climate overview of the Canadian inland seas. In: Martini IP (ed) Canadian inland seas. Elsevier Oceanography Series 44. Elsevier Science, Amsterdam, p 79-99

Montevecchi WA (2007) Binary dietary responses of northern gannets Sula bassana indicate changing food web and oceanographic conditions. Mar Ecol Prog Ser 352: 213-220

Overland JE, Alheit J, Bakun A, Hurrell JW, Mackas DL, Miller AJ (2010) Climate controls on marine ecosystems and fish populations. J Mar Syst 79:305-315

Piatt JF, Harding AMA, Shultz M, Speckman SG, van Pelt TI, Drew GS, Kettle AB (2007) Seabirds as indicators of marine food supplies: Cairns revisited. Mar Ecol Prog Ser 352:221-234

Prinsenberg SJ (1986) On the physical oceanography of Foxe Basin. In: Martini IP (ed) Canadian inland seas. Elsevier, Amsterdam, p 217-236

Provencher JF, Elliott KH, Gaston AJ, Braune BM (2013) Networks of prey specialization in an Arctic monomorphic seabird. J Avian Biol 44:551-560

Pyke GH (1984) Optimal foraging theory: a critical review. Annu Rev Ecol Syst 15:523-575

Pyke GH, Pulliam HR, Charnov EL (1977) Optimal foraging: a selective review of theory and tests. Q Rev Biol 52: 137-154

Renner HM, Mueter F, Drummond BA, Warzybok JA, Sinclair EH (2012) Patterns of change in diets of two piscivorous seabird species during 35 years in the Pribilof Islands. Deep-Sea Res II 65-70(Spec Issue): 273-291

Rühland KM, Paterson AM, Keller W, Michelutti N, Smol JP (2013) Global warming triggers the loss of a key Arctic refugium. Proc R Soc Lond B Biol Sci 280:20131887

Schrimpf MB, Parrish JK, Pearson SF (2012) Trade-offs in prey quality and quantity revealed through the behavioural compensation of breeding seabirds. Mar Ecol Prog Ser 460:247-259

Scott WB, Scott MG (1988) Atlantic fishes of Canada. University of Toronto Press

Shannon CE (1948) A mathematical theory of communication. Bell System Tech J 27:379-423 and 623-656

> Smith PA, Gaston AJ (2012) Environmental variation and the demography and diet of thick-billed murres. Mar Ecol Prog Ser 454:237-249

> Spencer M, Mieszkowska N, Robinson LA, Simpson SD and others (2012) Region-wide changes in marine ecosystem dynamics: state-space models to distinguish trends from step changes. Glob Change Biol 18:1270-1281

Springer AM, Byrd GV, Iverson SJ (2007) Hot oceanography: planktivorous seabirds reveal ecosystem responses to warming of the Bering Sea. Mar Ecol Prog Ser 352: 289-297

Stammerjohn S, Massom R, Rind D, Martinson D (2012) Regions of rapid sea ice change: an inter-hemispheric seasonal comparison. Geophys Res Lett 39:L06501, doi: 10.1029/2012GL050874

Statsoft (2005) Statistica 7.1. Statsoft Inc., Tulsa, OK

Stewart DB, Barber DG (2010) The ocean-sea ice-atmosphere system of the Hudson Bay complex. In: Ferguson $\mathrm{SH}$, Loseto LL, Mallory ML (eds) A little less Arctic. Springer-Verlag, New York, NY, p 1-37

Takahashi A, Kuroki M, Niizuma Y, Kato A, Saitoh S (2001) 
Importance of the Japanese anchovy (Engraulis japonicus) to breeding rhinoceros auklets (Cerorhinca monocerata) on Teuri Island, Sea of Japan. Mar Biol 139: 361-371

> Thaxter CB, Daunt F, Grémillet D, Harris MP and others (2013) Modelling the effects of prey size and distribution on prey capture rates of two sympatric marine predators. PLOS ONE 8:e79915

Editorial responsibility: Yves Cherel, Villiers-en-Bois, France
Waluda CM, Hill SL, Peat HJ, Trathan PN (2012) Diet variability and reproductive performance of macaroni penguins Eudyptes chrysolophus at Bird Island, South Georgia. Mar Ecol Prog Ser 466:261-274

Woo KJ, Elliott KH, Davidson M, Gaston AJ, Davoren G (2008) Individual specialization in diet by a generalist marine predator reflects specialization in foraging. J Anim Ecol 77:1082-1091

Submitted: December 6, 2013; Accepted: July 11, 2014 Proofs received from author(s): September 26, 2014 